\title{
A RECONSIDERATION OF THE GENUS EPIPOMPILUS (HYMENOPTERA: POMPILIDAE) ${ }^{1}$
}

\author{
By Howard E. Evans \\ Museum of Comparative Zoology
}

The genus Epipompilus was described by Kohl in 1884 , with maximiliani Kohl, from Mexico, as type. It was next treated by Ashmead in 1902, who at the same time described a related genus, Aulocostethus, with bifasciatus Ashmead, from "Peru", as type, Haupt, in 1930, erected the tribe Epipompilini for these two genera and several others; the others were shortly thereafter removed to another tribe. In 1944 Bradley presented a revision of the American species of Epipompilus and Aulocostethus. Ashmead, Haupt, and Bradley all separated the two genera by whether or not the eyes are hairy. Since Ashmead said that Epipompilus has glabrous eyes, it is clear that he was unfamiliar with the genus; and both Haupt and Bradley admit they had never seen the genus. Thus we have the curious phenomenon of a genus being treated by three persons, none of whom had ever seen any specimens belonging to the genus as he conceived it. As a matter of fact the eyes of maximiliani are hairy, and Epipompilus as conceived by these three workers is a nonexistent genus: in actuality the name Epipompilus is a senior synonym of Aulocostethus.

This is only one of several sources of confusion in the genus. Ashmead described Aulocostethus by merely placing it in a key and listing bifasciatus n. sp. as type. His description of bifasciatus can be and has been considered valid, but he gives no information other than the generic characters and the type locality ("Peru"), not even as to color pattern, which is of much value in separating species in this genus. Haupt used Ashmead's name for a specimen from Costa Rica, while Bradley, unable to find Ashmead's type, followed Haupt while expressing doubt that he had correctly identified Ashmead's species. However, there is a specimen in the U. S. National Museum labeled as Aulocostethus bifasciatus Ashmead in Ashmead's handwriting and marked as type of that species. But to add to the confusion this specimen bears the locality Bahia, Brazil, not "Peru" as it should. Now Costa Rica (Haupt's specimen) is actually closer to Peru than is Bahia, Brazil, but I find it hard to reason away the identification label in Ashmead's handwriting. Specimens of this genus are so rare that one is unlikely to make an error in labeling; in fact I doubt if Ashmead

\footnotetext{
${ }^{1}$ Published with the aid of a grant from the Museum of Comparative Zoology at Harvard College.
} 
ever saw any other specimens of the genus. On the other hand, Ashmead was a sufficiently careless person so that it is quite believable that he may have jotted down "Peru" when he meant "Brazil". At any rate, I accept this as the type of bifasciatus and have presented a description of it below, along with a new name for Haupt's specimen from Costa Rica.

Still further problems remain. Was Ashmead correct in placing maximiliani in the synonymy of Cresson's aztecus, or was Bradley correct in resurrecting it? If Epipompilus and Aulocostethus are synonyms, what is the status of Banks' Epicostethus, said to share some of the characters of both genera? What is the correct generic placement of Epipompilus insularis Kohl, from New Zealand? Finally, what is the male sex of Epipompilus?

On the following pages I have presented a brief synopsis of Epipompilus in which answers to all of these questions are proposed. I do not mean to imply that all problems in the genus are solved: my synopsis is based on a mere 18 specimens of these exceedingly rare insects. There are doubtless undiscovered species, and the males of most of the species have yet to be found. But at least I hope that I have supplied a sounder framework for future studies than has previously been available.

\section{Genus Epipompilus Kohl}

Epipompilus Kohl, 1884. Verh. K. K. Zool.-Bot. Gesell. Wien, 34: 57. [Type species: Epipompilus maximil ani Kohl, 1884 (=aztecus Cresson 1869) (designated by Ashmead, 1900)].

Aulocostethus Ashmead, 1902, Canad. Ent., 34: 132. [Type species: Aulocostethus bifasciatus Ashmead, 1902 (monobasic and original designation)]. New synonymy.

Epicostethus Banks, 1947, Bull. Mus. Comp. Zool., 99: 445. [Type species: Epicostethus will:amsi Banks, 1947 (monobasic)]. New synonymy.

Generic characters. - Maxillary palpi unusually elongate, antepenultimate segment the longest and distinctly longer than third antennal segment; labial palpi with the penultimate segment broadly ovate, the ultimate segment attached to one side of it; mandibles stout, rather smooth, with a few setae but without a lamina on the inferior margin which subtends a fimbriate groove, inner margin with a single strong tooth well back from apex; labrum partially exserted, broad and short, apical margin of clypeus broadly truncate or arcuately concave; flagellum with rather coarse, bristling, semi-erect pubescence, particularly on the inner side of the basal segments of the female and on the outer side of the entire flagellum of the male; head broader than high, front with distinct small punctures; eyes densely covered with short hairs (reduced and scarcely noticeable in some females and in 
the known males); front rather swollen above, between the antennal bases abruptly declivous to the much lower plane of the area frontalis and clypeus. Pronotum short or fairly long, sides of disc rather prominent, streptaulus absent or ill-defined; mesoscutellum and metanotum prominent medially, latter with distinct lateral foveae; postnotum of variable length, front and hind margins subparallel; propodeum with smooth contours, slope low and even, almost flat behind; front femora of female slightly to quite noticeably incrassate; front tibiae and tarsi without spines, middle and hind tibiae with or without scattered short spines; segments of front tarsus of female unusually short; claws slender, with a strong, subapical tooth which is nearly parallel to the apical tooth; ultimate tarsal segments without spines beneath, pulvillar pads small but giving rise to some strong setulae. Hind wing with anal lobe small, about $.3-.5$ as long as submedian cell, anal vein extending very slightly or not at all beyond junction of transverse median vein, latter vein leaving it at an angle, oblique, meeting media much before origin of cubitus; fore wing with venation extending relatively close to outer wing margin, marginal cell acute, removed from wing-tip much less than its own length; three submarginal cells present, second and third receiving recurrent veins near middle, third much wider at apex than at base. Abdomen fusiform, in the female somewhat depressed apically, apical sternite rather flat, even obscurely grooved medially; male with or without conspicuous brushes of hair on sternites four and five, subgenital plate of remarkable structure, forming a very slender, hairy process apically, its basal plate (morphological sternite 8) unusually broad; male genitalia with short, simple parameres, volsellae short-setose, not expanded apically, basal hooklets double, aedoeagus small and of simple structure.

Remarks. - Epipompilus possesses a remarkable array of unusual structural features; if one follows the practice of Bradley and Arnold of splitting the Pompilinae into numerous tribes, there can be no question that the genus deserves a tribe of its own. Personally, I am much impressed with certain similarities with Aporus and related genera: the pronotum is similar, the front legs of the female somewhat incrassate, and the head shape and hairiness of the eyes suggestive of certain Aporini. The male genitalia suggests Allaporus, as does the venation of the hind wing. Any division of the Pompilinae into tribes can be no more than tentative until such time as the classification of the family from a world point of view is more satisfactorily worked out. In the meantime, I prefer to place Epipompilus in the Aporini. As here construed, the genus Epipompilus is strictly Ncotropical 
is distribution. However, Kohl included a New Zealand species, insularis Kohl, in his conception of the genus, and various workers since have listed Epipompilus from the Australian region. I have studied two females determined by Banks as insularis and agreeing well with Kohl's description of this species. There can be no question that this species is closely related to the several Neotropical species of Epipompilus. Indeed, it agrees well with the above diagnosis except in the following characters (the males are unknown): maxillary palpi not greatly lengthened, about as usual in the family; labial palpi unmodified; eyes with only minute, scarcely noticeable hairs; transverse median vein of hind wing reaching media a short distance before origin of cubitus. The generic name Epipompiloides is here proposed for insularis Kohl, I884. I know of no other species assignable to this genus, but the pompilid fauna of the Australian region is, of course, very inadequately known. This genus is related to Epipompilus and should be placed in the Aporini next to that genus.

Key to known species of the genus Epipompilus

\section{Males}

Antennae moderately long, crenulate in profile; claws of front tarsus nearly alike; thorax in considerable part rufous; parameres of genitalia with extremely long hairs, abdominal venter with hairtufts 9. innubus $\mathrm{n}$. sp.

Antennae very short, with coarse, dark pubescence but only very weakly crenulate in profile; outer claws of front tarsus much more strongly curved than inner claws; thorax black; parameres and abdominal venter with only short hairs .......6. excelsus (Bradley)

\section{Females}

I. Wings wholly fuliginous; abdomen wholly rufous; pronotum patterned with red and black (Florida and Bahamas)

I. pulcherrimus (Evans)

Wings hyaline, fore wing with two prominent brownish bands; abdomen not wholly rufous, more or less patterned with black, rufous, and/or whitish, pronotum all black or all rufous .... 2

2. Abdomen black, with a pattern of whitish spots ................... 3

Abdomen in part rufous, with or without whitish spots ........ 5

3. Body wholly black except for a pair of whitish spots on second abdominal tergite; hind tibiae with a few short spines; pronotum very short, subangulate behind (Ecuador)

2. williamsi (Banks)

Thorax largely rufous; hind tibiae without spines 
4. Abdomen with whitish markings on tergites 2 and 5, none on sternites; posterior lobes of pronotum rufous (Mexico)

3. aztecus (Cresson)

Abdomen with whitish markings on tergites 2, 3, 4, and 5, also on sternites 2 and 3 ; posterior lobes of pronotum whitish (Brazil)

4. bifasciatus (Ashmead)

5. Size larger (8-I I mm.) ; abdomen with whitish markings on tergite five, this tergite otherwise black (Brazil) ................. 6

Size small (6-7 mm.); abdomen not marked with whitish on tergite five, tergites five and six brownish-ferruginous (Central America)

6. Antennae black; propodeum black except for limited yellowish markings; hind tibiae unarmed 5. haupti (Arlé)

Antennae rufous except darker apically; propodeum wholly rufocastaneous; hind tibiae weakly spinose ...6. excelsus (Bradley)

7. Second abdominal segment with a pair of whitish spots; hind tibiae unarmed (Panama) .......................7. delicatus Turner

Second abdominal tergite without whitish spots; hind tibiae with scattered, short spines (Costa Rica) ...........8. insolitus n. name

I. Epipompilus pulcherrimus (Evans) new combination

Aulocostethus pulcherrimus Evans, 1955, Ent. News, 66: 150. [Type: $q$, Everglades Nat. Park, Florida, 30 December 1953 (U. S. Nat. Mus.) ].

Remarks. - Since describing this species from the unique type, I have seen one additional specimen, from Mangrove Cay, Andros Island, May-June i9i7 (W. M. Mann) [Amer. Mus. Nat. Hist.]. This specimen agrees well with the type except that it is smaller (about $5 \mathrm{~mm}$. long, fore wing $4.3 \mathrm{~mm}$.) and the pronotum has a broad median streak of pale rufous as well as being rufous anteriorly and posteriorly. This species is colored quite differently from any other. The pronotum is much shorter than in aztecus, nearly as short as in williamsi. The claws are the same as in aztecus and other species of the genus, my statement to the contrary in the original description being in error.

2. Epipompilus williamsi (Banks) new combination

Epicostethus williamsi Banks, 1947, Bull. Mus. Comp. Zool., 99: 446. [Type:

․ Baños, Oriente, Ecuador, 6000 feet, 30 Oct. (Mus. Comp. Zool.)].

Remarks. - Bank's description is detailed and there is no reason to repeat it here. The pronotum is short and subangulate behind, the front femora are barely incrassate, and the hind tibiae have several spines. The first two of these characters are shared (more or less) 
with pulcherrimus and delicatus, the third with insolitus, excelsus, and innubus. Thus the species is not as unique as Banks supposed, and his generic name must be added to the synonymy of Epipompilus. I have seen no specimens of this species other than Banks' type.

3. Epipompilus aztecus (Cresson) new combination

Ferreola azteca Cresson, 1869, Proc. Boston Soc. Nat. Hist., 12: 376 [Type: $\odot$, Veracruz, Mexico (Acad. Nat. Sci. Phila.) ].

Epipompilus maximillian. Bradley, 1944, Trans. Amer. Ent. Soc., 70: 146 34: 57 [Type: 9 , Cuernavaca, Mexico, 1871 (Bilimek) (Vienna Mus.)].

(Placed in synonymy with azteca by Ashmead, 1902). - Haupt, 1930, Mitt. Zool. Mus. Berlin, 16: 762.

Epipomplus maximilliani Bradley, 1944, Trans. Amer. Ent. Soc., 70: 146 (Misspelling of maximiliani Kohl).

Aulocostethus aztecus Bradley, 1944, ibid., p. 142.

Remarks. - Bradley has recently provided a detailed description of this species, drawn from Cresson's type of azteca. He states that this specimen "does not at all agree with Kohl's description of maximiliani". Since I found myself unable to agree with this statement, I asked to borrow the type of maximiliani from the Vienna Museum for comparison. At first the type could not be located, but later Dr. R. M. Bohart visited the museum and at my request searched for and found it; Dr. Max Fischer then sent it to me by mail, and I took it to Philadelphia and compared it directly with the type of azteca. I am very much indebted to Drs. Bohart and Fischer for their assistance with this problem.

The two type specimens differ considerably in size, that of aztecus being much larger, $13.5 \mathrm{~mm}$. long, fore wing IO $\mathrm{mm}$.; maximiliani measures $7.5 \mathrm{~mm}$. long, fore wing $6 \mathrm{~mm}$. The front femora are slightly more incrassate in aztecus $(2.6 \times$ as long as maximum width as compared to $2.75 X$ in maximiliani). The whitish maculations are exactly the same in the two specimens, but they type of aztecus has the posterior third of the propodeum blackish and the middle and hind legs blackish except for the white spurs and white streaks on the hind tibiae; in the type of maximiliani the propodeum is wholly rufous, the middle and hind coxae rufous above, the middle and hind femora rufous, and the tibiae partially suffused with rufous. Besides these two specimens, I have seen one other, a female from Cuernavaca, taken by my wife inside the window of a house on March 24, 1959. This specimen is about the same size as the type of aztecus, from Veracruz, and the front femora are incrassate to the same degree. However, the propodeum is wholly rufous (as in the type of maximiliani, also from Cuernavaca) and the leg coloration intermediate between that of the two types (middle femora rufous, hind femora 
black, middle tibiae slightly suffused with rufous but hind tibiae black and whitish, middle and hind coxae with a small amount of rufous above). There is no question at all in my mind that these three specimens are conspecific.

4. Epipompilus bifasciatus (Ashmead) new combination Aulocostethus bifasciatus Ashmead, 1902, Canad. Ent., 34: 132 [Type: Bahia, Brazil, 19 March 1883 (but stated by Ashmead to be "Peru") (U. S. Nat. Mus., no. 58858) ]. (Not Aulocostethus bifasciatus of Haupt, 1930; see no. 8, insolitus n. name).

Description of type female. - Length I I $\mathrm{mm}$., fore wing $8.7 \mathrm{~mm}$. Head black; inner orbits narrowly pale yellow up to emargination of eyes; antennae wholly brownish, darker apically; apical half of clypeus and labrum pale yellowish; mandibles dull rufous; palpi light reddish-brown. Thorax rufo-castaneous, except mesonotum with black streaks over wing bases, and the following pale yellow: posterior lobes of pronotum, extreme lower posterior corner of mesopleurum, posterior rim of propodeum (interrupted medially), and apical posterior parts of middle and hind coxae; legs otherwise reddish like thorax, middle and hind tibiae weakly infuscated, spurs all whitish. Abdomen black, spotted with pale yellow (almost white) as follows: two large lateral spots on tergite two, two much smaller spots on tergite three, two spots on tergite four slightly larger than those on three, two large spots on tergite five broadly connected by a basal band; also sternites two and three with small lateral spots. Wings bifasciate, hyaline with a strong band over the basal and transverse median veins and a broader band filling the marginal cell and extending to the posterior wing margin. Body and legs clothed with short, white hair; eyes short-haired.

Clypeus broadly truncate; labrum small, exserted. First four antennal segments in a ratio of about $13: 5: 11: 12$, segment three .55 $X$ upper interocular line. Head $1.2 \times$ as broad as high; middle interocular line $.57 \times$ width of head; upper interocular line $.8 \times$ lower interocular line. Ocelli in a broad, flat triangle, front angle greater than a right angle; postocellar line much greater than ocello-ocular line. Pronotum of moderate length, posterior margin subangulate. Propodeum with smooth contours except posterior slope finely transversely striolate and with rather long pubescence; median line not impressed. Posterior tibiae without spines. Fore wing with basal and transverse median veins interstitial; radial vein somewhat angulate at junction of second intercubital vein, marginal cell removed from wingtip by about .7 its own length.

Remarks. - This is a rather typical member of the genus, in fact 
rather close to aztecus. As mentioned in the introduction, Ashmead provided no real description of the species, and Bradley did not see the type and therefore followed Haupt, who had misidentified the species. Presumably Ashmead was merely in error when he gave "Peru" as the type locality of the species, as the type is labeled in Ashmead's handwriting.

5. Epipompilus haupti (Arlé) new combination

Aulocostethus haupti Arlé, 1936, Festschr. für Embrik Strand, 1: 514 [Type: 9, Serra do Realengo, Rio de Janeiro, Brazil, 7 Oct. 1934]. - Bradley, 1944, Trans. Amer. Ent. Soc., 70: 144. -Banks, 1947, Bull. Mus. Comp. Zool., 99: 445.

Remarks. - Bradley has provided a translation of the description of this species. I have studied the specimen mentioned by Banks (Campinas, Brazil). The legs of this specimen are more extensively rufous than described for the type, but there is agreement in most other details; the eyes of this species are more weakly hairy than is usual in the genus.

\section{Epipompilus excelsus (Bradley) new combination}

Figs. 3 and 4

Aulocostethus excelsus Bradley, 1944, Trans. Amer. Ent. Soc., 70: 143 [Type: + , Nova Teutonia, Santa Catarina, Brazil, 25 January 1939 (Mus. Comp. Zool.) ]. -Wahis, 1957, Bull, Ann. Soc. R. Ent. Belg., 93 : 47-49 (Remarks on color variation).

Remarks. - I have seen several additional females of this species from the type locality, as well as a female from Rio de Janeiro, October 1938 (R. C. Shannon) [U. S. Nat. Mus.]. The type, as well as all the other specimens I have seen, has a pair of connected whitish spots on the fifth tergite, Bradley's description being in error on this point. Wahis has discussed this matter and also pointed out that some specimens have whitish markings on the second and sixth tergites.

A male Epipompilus in the Canadian National Collections, Ottawa, is almost certainly that of excelsus, even though it is colored very differently from the female. Like the type female excelsus, it was taken at Nova Teutonia, Brazil, by Fritz Plaumann, in this case on 19 June 1946. The spinose hind tibiae, as well as the locality, suggest that this male belongs here rather than with haupti or bifasciatus.

Description of male. - Length $5.8 \mathrm{~mm}$., fore wing $4.8 \mathrm{~mm}$. Body wholly shining black, with a weak bluish luster; face with a pair of small whitish spots beside and below the antennal sockets, next to the eyes; apical two thirds of mandibles whitish, the teeth rufous; palpi 
light brown; antennae dark brown; tegulae dark brown; front and middle legs with the coxae black, suffused with brown apically, remainder of these legs brown, middle femora with a tinge of rufous, front tibiae yellowish-brown; hind legs wholly black except tibia with a sub-basal whitish spot which nearly encircles them; fore wing weakly tinged with brownish, especially along the basal vein and on the apical third, setulae dark, veins and stigma brown.

Maxillary palpi with segments $3-6$ in a ratio of about $15: 19: 15: 13$. Mandibles with a single large tooth well back from apex. Clypeus arcuately emarginate apically, exposing the small labrum. Eyes strongly convergent below, lower interocular line about $.75 \times$ upper interocular line; middle interocular line. $.59 \times$ width of head; head about $1.15 X$ as wide as high; ocelli in a broad triangle, postocellar line $\mathrm{I} .3 \times$ ocello-ocular line. Front with distinct punctures which are separated by about their own diameters. Eyes with minute hairs except near the tops, where they are somewhat longer. First four antennal segments in a ratio of about 1 5:5:8:9, segment three about I. $6 \times$ as long as thick; flagellum short, very weakly crenulate in profile, with coarse, dark pubescence which is especially long and suberect on the upper and outer sides of the basal segments.

Pronotum of moderate length, its posterior margin subangulate. Mesonotum wholly and uniformly covered with small punctures. Postnotum nearly as long as metanotum, polished, with a median impression and some weak basal striations. Propodeum with the slope low and even; median line not impressed. Femora slender; middle tibiae with a few spines, hind tibiae with many fairly strong spines above; all tarsi weakly spinose; longer spur of hind tibiae nearly as long as basitarsus. Claws with the inner tooth of all claws strong, sloping so that the claws appear bifid; outer claws of front tarsus much more strongly curved than inner claws. Fore wing with basal vein arising a very short distance beyond transverse median vein, basal part of basal vein distinctly arched; marginal cell large, acute apically, radial vein distinctly angulate at its junction with the second transverse cubital vein.

Abdomen fusiform, covered with short setae but without distinct ventral hair-brushes. Subgenital plate (fig. 3) consisting of a long, hairy apical process arising from a basal section which also bears some long hairs. Genitalia (fig. 4) with the parameres weakly setose; volsellae simple, weakly setose; basal hooklets large, double; parapenial lobes somewhat knobbed apically, very slightly exceeding the volsellae. 

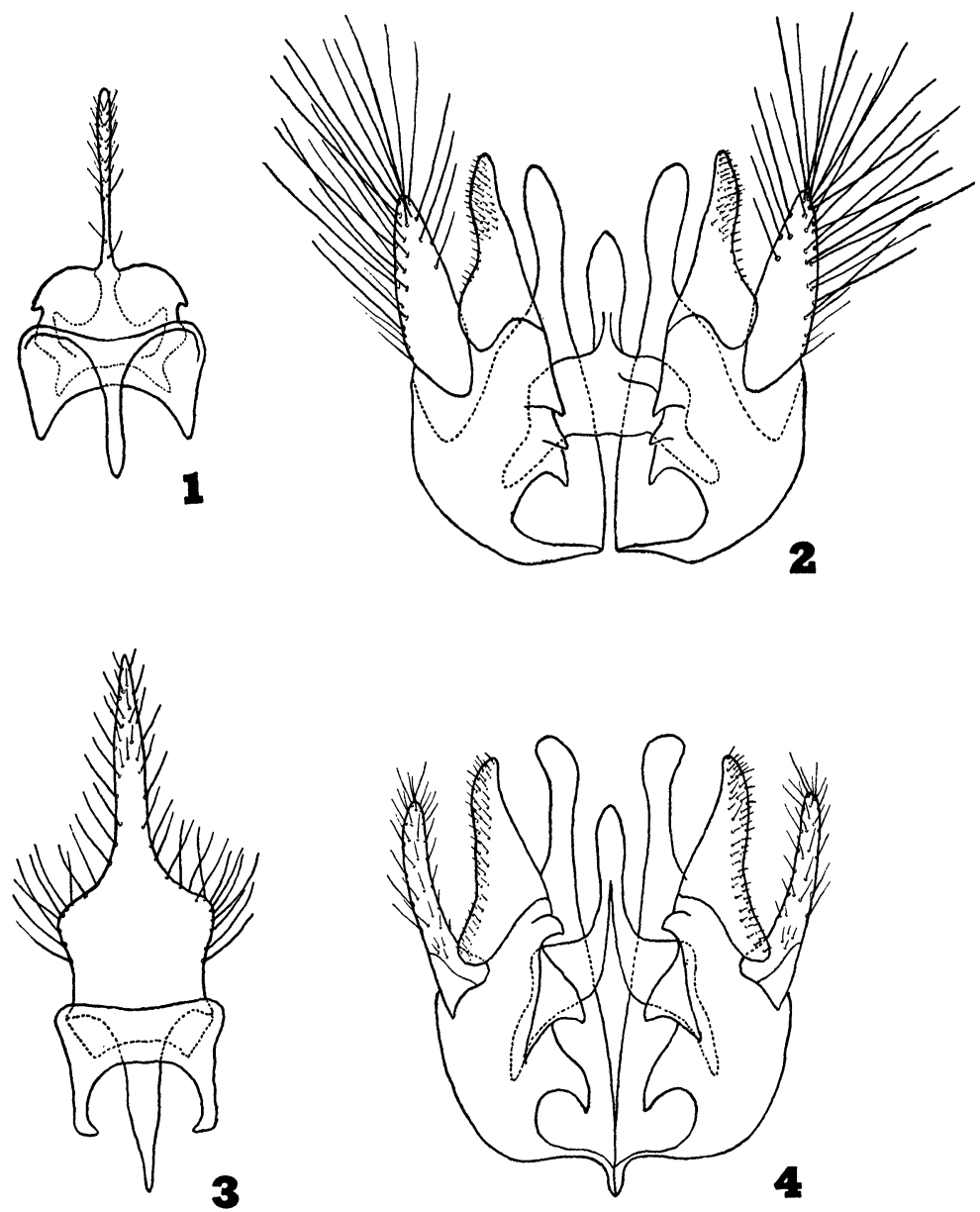

FIg. 1 Subgenital plate of Epipompilus innubus new species. FIg. 2 Genitalia of E. innubus. Fig. 3 Subgenital plate of E. excelsus (Bradley). Fig. 4 Genitalia of $E$. excelsus. All figures show the ventral aspect. 


\section{Epipompilus delicatus Turner}

Epipompilus delicatus Turner, 1917. Ann. Mag. Nat. Hist., (8) 20:359 [Type: + , Bugaba, Panama (Champion) (British Mus.) ]. - Bradley, 1944, Trans. Amer. Ent. Soc., 70: 146.

Remarks. - I have not seen the type of this species, nor had Bradley. It is a small species, comparable in size to pulcherrimus and insolitus. It is reported to have a short pronotum and unarmed hind tibiae, as well as a color pattern distinct from that of other species.

\section{Epipompilus insolitus new name}

Aulocostcthus bifasciatus Haupt, 1930. Mitt. Zool. Mus. Berlin, 16: 763. Bradley, 1944, Trans. Amer. Ent. Soc., 70: 145 (Nec Ashmead, 1902, Canad. Ent., 34: 132; misidentification).

Type. - o, Turrialba, Costa Rica (Coll. H. Haupt, Halle/Saale, Germany).

Description (from Haupt, I930). - Length $7 \mathrm{~mm}$. Yellowishbrown, the following black: head, apical half of antennae, tergites I, 3 , and 4, apex of hind femora, and outer base of hind tibia. Fore wing with two dark brown bands. Hind tibiae with a whitish area behind the black base, tips of front and hind coxae also whitish. Whole body with short, thick whitish hair; eyes and wings hairy.

Wings (Haupt's fig. 64) yellowish-hyaline, a brown transverse band before the middle and one before the apex. Fore wing with three cubital cells, the second somewhat pentagonal, the third trapezoidal, the latter removed from tip by its own length. Radial cell longer than second and third cubital cells together, also somewhat higher than these. Pterostigma cell-like, translucent, somewhat attenuate. Lower section of basal vein about twice as long as upper and weakly arched; transverse median vein interstitial. Hind wing with transverse median vein short, oblique, reaching media more than its own length before origin of cubitus.

Head thick, flattened and weakly concave immediately behind the eyes, temples barely developed. Ocelli large, forming a weakly acute angle in front, postocellar and ocello-ocular lines equal. Front strongly swollen, eyes thick, their inner margins subparallel, the eyes together about equal to width of front. Antennae filiform, relatively thick, third segment somewhat shorter than scape. Clypeus short, trapezoidal, its entire anterior margin weakly arcuately concave. Segments of maxillary palpi very long, third segment about ten times as long as thick (Haupt's fig. 65). Pronotum short, hind margin obtusely angled, sides parallel, with distinct longitudinal swellings. Mesoscutum twice as long as pronotum medially; scutellum and metanotum 
elevated. Postnotum distinct, half as long as metanotum, lightly impressed medially. Propodeum somewhat longer than broad, narrowed and less steeply sloping behind, without discernible sculpturing except indication of a median groove. Fore tarsi without a comb, second to fourth segments short, the second as long as broad, the following shorter. Hind tibiae with scattered, short spines. Claws slender, with a sharp tooth before the apex, also with a distinct fan of bristles (Haupt's fig. $84 \mathrm{~J}$ ) ; claw-comb with a very short plate, its barbules sparse, surpassing the pulvillus.

Remarks. - I have not seen this species, but since it has been described and figured by Haupt in considerable detail, it seems desirable to provide a name for it.

\section{Epipompilus innubus new species}

Figs. $x$ and 2

Type. - o $0^{x}$ Cucharas, $750 \mathrm{~m} .$, Valley of Huallaga, Dpt. Huanuco, Peru, June 1954 (F. Woytkowski) [Coll. H. K. Townes].

Description. - Length $6 \mathrm{~mm}$., fore wing $5.7 \mathrm{~mm}$. Head black except as follows: inner orbits pale yellow up to middle of eyes; clypeus, labrum, and mandibles pale yellow, almost white; palpi very light brown; antennal sockets connected by a light yellow band; first five antennal segments yellowish-brown below, dark brown above, rest of antenna nearly black. Thorax rufo-ferruginous except shining blue-black as follows: propleura and extreme anterior parts of pronotum, mesosternum and anterior half of mesopleurum, sides of metanotum, all of postnotum, all of metapleurum except upper anterior margin, all of propodeum except for sides of posterior rim, which are pale yellow. Coxae blackish except middle and hind coxae tipped with white; middle and hind trochanters blackish; front and middle legs otherwise light reddish-brown, hind legs nearly black except tarsi paler and tibiae with a white basal annulus; tibial spurs whitish except middle and hind spurs suffused with black basally. Abdomen shining blue-black except apical tergite ivory-white. Wings hyaline, with dark setulae, veins and stigma brown, fore wing weakly clouded in and about third submarginal cell.

Maxillary palpi very long, segments in a ratio of about 2:4:8:10:8:7. Mandibles rather smooth, with a few setae, inner margin with a strong tooth well back from apex. Labrum broad and short, truncate, exserted well beyond truncate apical margin of clypeus, latter about twice as broad as high. Front prominent above antennal orbits, narrow, middle interocular line .56 times width of head; head nearly I.2 $\times$ as wide as high; ocelli in a broad. flat tri- 
angle, postocellar line twice the ocello-ocular line. Front with distinct punctures which are separated by less than their own diameters. Eyes with very short, barely noticeable hairs. First four antennal segments in a ratio of about 1 5:5:13:12, segment three about twice as long as thick; each flagellar segment, but more particularly the middle ones, with a distinct swelling below and toward the base, giving the antennae a somewhat crenulate profile below.

Pronotum very short, its posterior margin subangulate. Mesonotum with distinct small punctures like the front; postnotum smooth, transversely striate, about half as long as metanotum. Propodeum with even contours, median line weakly impressed, surface of declivity very finely transversely striolate. Femora not notably swollen; middle and hind tibiae with short spines scattered amongst the pubescence; longer spur of hind tibia nearly as long as basitarsus; claws of front and middle legs strongly dentate, those of hind legs obscurely dentate. Fore wing with basal vein arising well beyond junction of transverse median vein, basal part of basal vein strongly arched; marginal cell large, acute, removed from wing-tip by only about half its length; other features of wing about as in other species of the genus.

Abdomen fusiform, covered with short setae; sternites four and five each with a transverse brush of longer setae, longer on the sides than medially, the setae curved at their tips; genitalia also giving rise to some long setae which protrude from sides of subgenital plate. Subgenital plate (fig. I) of unusual form, consisting of a long, slender, hairy process arising from complex basal plates (the modified ultimate and penultimate sternites). Genitalia (fig. 2) with parameres short, bearing some very strong setae; volsellae weakly setose, narrow in ventral view but mesal surface wide and concave; basal hooklets double, unusually well separated; parapenial lobes slightly shorter than volsellae; aedoeagus very small.

Remarks. - The spinose hind tibiae and short pronotum suggest williamsi as the possible female of this species, and the type localities of these two are not too far distant (Ecuador and Central Peru). However, the difference in coloration is great, and it seems to me best to consider the two distinct for the present. 

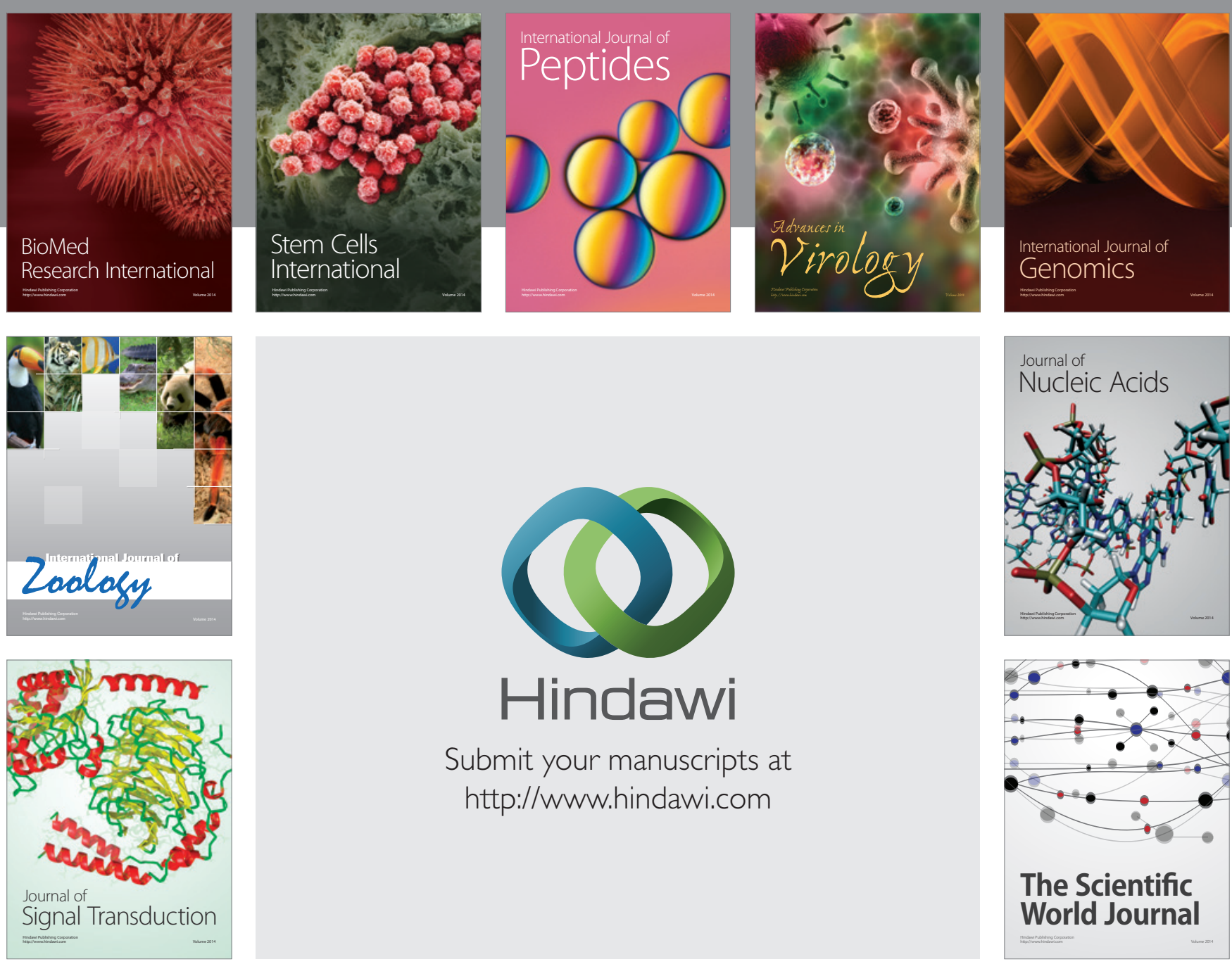

Submit your manuscripts at

http://www.hindawi.com
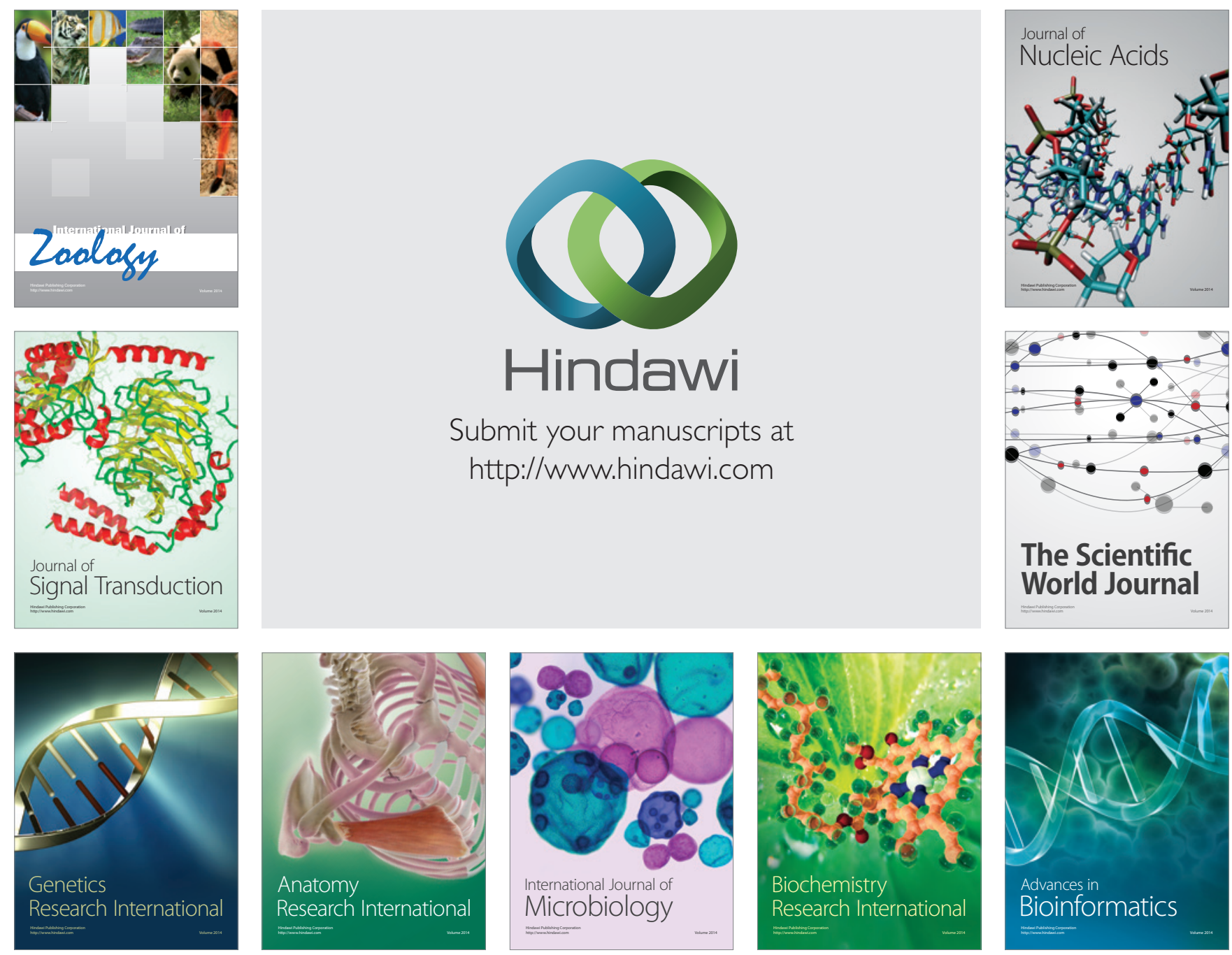

The Scientific World Journal
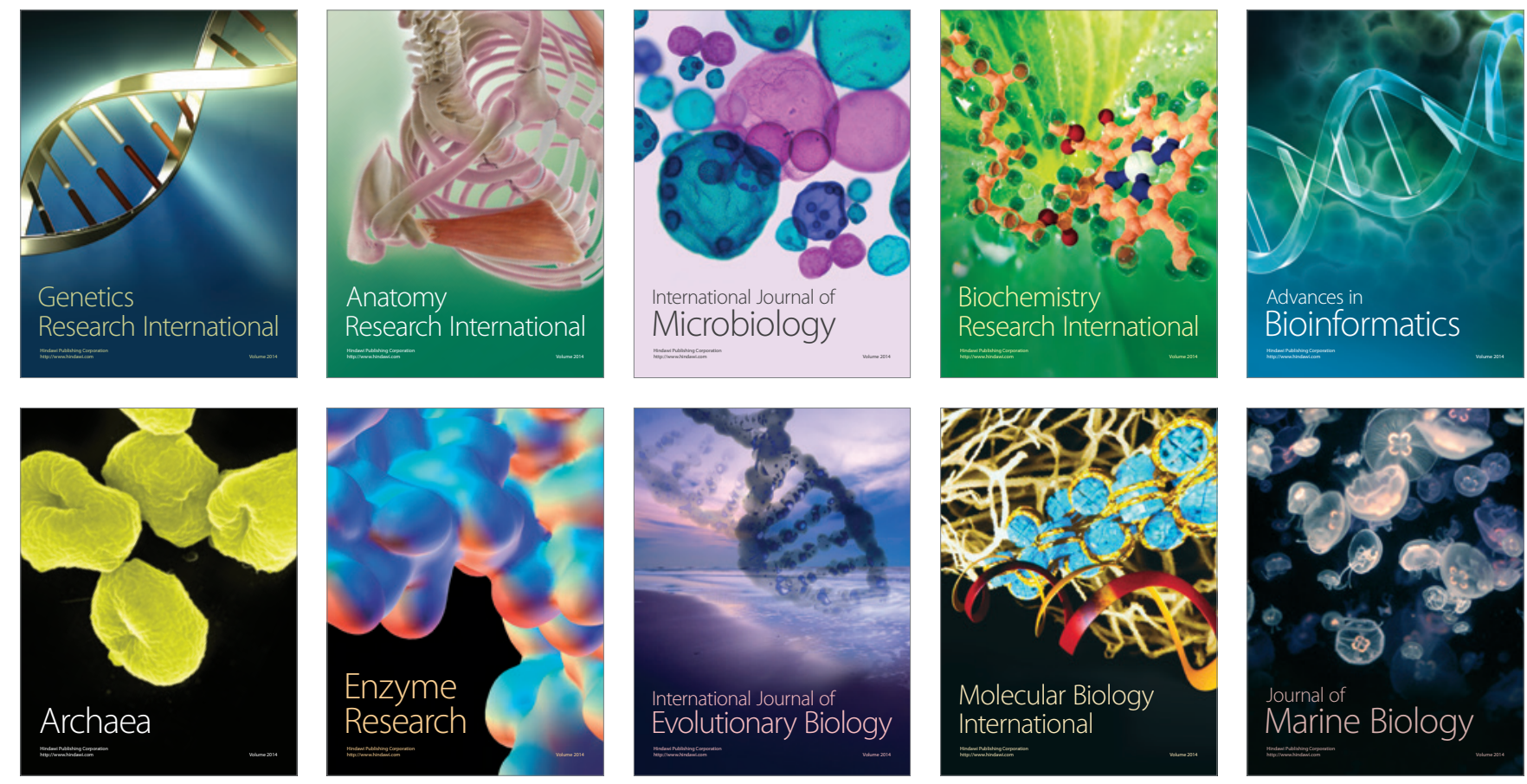